\title{
Local Wisdom and National Integration in Indonesia: A Case Study of Inter-Religious Harmony amid Social and Political Upheaval in Bunga Bondar, South Tapanuli
}

\author{
Rosmaida Sinaga, Flores Tanjung, Yuri Nasution \\ Department of History Education, Faculty of Social Sciences, \\ Universitas Negeri Medan, Indonesia
}

\begin{abstract}
This study emphasizes on inter-religious affairs happened in Bunga Bondar, South Tapanuli began to experience turmoil when the national movement era started in 1908 and it still happens to present-day. The Dutch colonial government advocated for inter-religious harmony at a local level. The policy was pursued by the the Dutch colonial government out of fear that the Indonesian people would develop a sense of unity and fraternity among them, thereby intensifying the spirit of

Received:

March 14, 2019

\section{Accepted:}

July 16, 2019

Corresponding Author:

sinaga.rosmaida@yahoo.com nationalism. The Dutch government's concern eventually came true when the power of the Christian wing of the national movement cooperated with its Islamic counterpart. Along with the political upheavals and social changes experienced by the Indonesian people, the harmony between religious groups in various regions was affected. Despite migration, changes of central and local leadership, and the flow of modernization that took place, the dynamics of inter-religious harmony of the 1930s are still present today. The tradition, the spirit of harmony, leadership models, and the application of local wisdom are all the key to the survival of inter-religious harmony in Bunga Bondar, South Tapanuli, as findings in research that can be used as a guide or model to build national integrity.
\end{abstract}

Keywords: Inter-Religious Harmony; Political and Social Upheaval; National Integrity.

\section{Introduction}

Social history is actually an alternative method that can be used to obtain various unusual perspectives to resolve problems arising from an event or historical phenomenon, so that the solution produced can be 'fresher' in terms of delivery and 'richer' in terms of material (Kuntowijoyo 2003, 39). Village unity as a theme of social history research has recently risen to prominence, despite a history of underestimation by older-generation historians. Village research is able to cast a light on the living reality of Indonesian people from a perspective that is 'fresher' than what has been presented so far. Village research can even reveal new facts that are equally important and interesting in describing the life of Indonesian society in the past.

The field research was located in Bunga Bondar village. It was carried out not only because of the long history of the said village, both as an administrative unit and as part of a region with high level significance in the era of Dutch colonial rule. In Sipirok there is a particular social phenomenon, namely the retention of harmony between Muslims and Christians. Bunga Bondar is part of the administrative area of Sipirok District. The Sipirok region serves as the boundary between the northern part of Tapanuli and the southern part of Tapanuli, both administratively and culturally. The northern part of Tapanuli is inhabited by the predominantly Christian Toba Batak sub-tribe, while the southern part is inhabited by the predominantly Muslim Batak AnggkolaMandailing sub-tribe. The Sipirok area is located right in the middle of the two regions. In Sipirok you can find a mixed population of both religious identities. 
The first record of inter-religious phenomena dates back from the beginning of the national movement spirit in the Sipirok region. Since then the inter-religious harmony in Bunga Bondar continued to experience ups and downs and the impact of such dynamics was felt even beyond the region. How such events and phenomena occurred during the period of the 1930 to the Reformation period can explain the underlying phenomenon of this research. The author tries to give an explanation in the form of the emergence of a tradition of inter-religious harmony that took place before the time of independence until the beginning of the Reformation, as well as why the villagers are capable to maintain inter-religious harmony amid political, social and cultural changes, so that it can be a model to build national integrity.

\section{Inter-religious Affairs}

Islam entered into the Bunga Bondar almost simultaneously with that of Christianity. The presence of Christianity in the village was marked by the establishment of a post by the RMG, a German Christian missionary institution, in 1860 (Marpaung 2010, 12). This situation conditioned Bunga Bondar to become a significant place for spreading religion in southern Tapanuli, especially Christianity. Before the coming of Islam or Christianity into the area, the people adhered to an animistic belief called Sipelebegu. The government is led directly by Sipukka Huta (who first opened and inhabited the village). Lintong Siregar, called Mangaraja or king, was known later in the early $19^{\text {th }}$ century. The villagers at that time began to embrace both Islam and Christianity. The then-ruling king along with the village community agreed to adapt the laws and traditions which had existed since the village had been founded with those regulating religious communities in order to avoid conflicts sparked by social change.

An example of such laws and traditions, namely the tradition of marjambar (exchanging food among citizens) is still practiced today. Before the entry of Islam and Christianity, the citizens used to perform the marjambar tradition when conducting traditional ceremonies. After the coming of both religions, the marjambar tradition was adapted to Eid al-Fitr and Christmas Day. During Eidal-Fitr celebrations, Muslim citizens give festive food to their Christian neighbors and relatives. Conversely, when Christmas celebrations come, Christians will give Christmas specialties to their Muslimn neighbors and relatives. During religious holidays, villagers collect money from all residents to buy and slaughter bulls. In addition, there is also a law that prohibits Christians to bring processed pork into the village. This is intended to make Muslims feel comfortable going out and going to their Christian friends' homes without fear of being contaminated by something that is considerred as prohibited (haram) according to the Islamic doctrine. Meanwhile, the practice of social tolerance regarding romantic relationships among youths of different religions was based on the patrilinear system of the Batak tribe. Therefore, if the relationship between the love of young people of different religions should continue into marriage, the bride would have to convert and adopt her future husband's religion. This is based on the Batak Tribe's patrilinear system that position of male as the head of the family and who inherit the family name to their children.

\section{The Ups and Downs of Inter-Religious Harmony}

The inter-religious harmony at Bunga Bondar began to experience turmoil when the echoes of the national movement reached Sipirok in 1930 from the north (Aceh) and from the south (Minangkabau), both of which were predominantly Muslim, when the Dutch colonial government had officially occupied the Sipirok area (Lance 2001, 76). The colonial government was concerned that the influence of the anti-Dutch spirit would complicate the pursuit of its interests. On the basis of political considerations, the Dutch colonial government in Sipirok always sided with Christians and denied Muslims. The colonial government was worried that if the entire community of different religions had a strong sense of unity and brotherhood, it would foster a spirit of nationalism in Sipirok, as was the case in other regions in Indonesia. The Dutch colonial government had tried to pit Muslims and Christians against each other by publishing a pamphlet 
which defamed Islam and pitted kings against one another. The Dutch colonialists' fear eventually materialized when the might of Christian axis of the national movement, the Manullang-led Huria Christian Batak (HKB), entered Sipirok in 1930 in cooperation with the Islamic axis of the national movement (Serikat Islam/ SI) which had previously entered to Sipirok region (Lance 2001, 76). Good coordination betweenboth influential groups made it difficult to pursue Dutch interests in Sipirok.

HKB and SI proved able to unite the Sipirok people of different religions in a single regional spirit, and even nationalism, and other organizations began to emerge such as Muhammadiyah, Partindo (1931) and Djamiatul Waslijah (1936). The Sipirok community finally realized that the polemic which had arisen between Muslims and Christians was a fighting contest established by the Dutch colonial government. When the highly educated people of Sipirok (the majority of whom are from Bunga Bondar, for example Manullang's wife, a prominent Southern Tapanuli advocate of education, B.M. Moeda and Soetan Josia Diapari) already had the same anti-Dutch spirit, tension between Muslims and Christians began to wear off.

During the Japanese occupation, social harmony was hardly visible because all the Indonesian people, including the villagers, suffered greatly from the Japanese occupation (Steele 2012). However, neither written sources nor interviews results managed to produce facts relating to interreligious harmony. This is expected because the Japanese administration at that time was very strict in controlling the daily lives of the villagers. For example, a person who showed some resistance because he refused to become romusha would be shot dead (Shigeru 1996). Likewise, the harmony between religious people at that time could not be deemed stable and good, since according to the philosophy of the Bunga Bondar community the harmony between religious communities is part of harmony between fellow humans. As such, the situation during the Japanese occupation did not fulfill these prerequisites.

In the era of Japanese occupation, Indonesia was never safe for long enough to restabilize the ravaged society. The Dutch Military Aggression, the PRRI/Permesta rebellion up to the G30S event resulted in economic, security and social crises, so that the tradition of social harmony was almost silent at that time (Lindsay 2012). Security instability had a major influence on the inter-religious harmony among the people of Bunga Bondar.

The Old Order period was a difficult time for all the people of Indonesia, including the villager. Therefore, during this period, various practices of the social harmony tradition between Muslims and Christians could not be carried out properly due to the lack of stability in terms of security, famine and war that continued to haunt the people. The people can only remember about the practice of interreligious harmony tradition in the 1960s, when the Muslim congregation all but held a marjambar tradition with Christians at the church for the New Year's celebration (Kymlicka 2011, 29). However, the spirit of harmony was not lost and instead appeared in the spirit of unity which was shown not only by the people of Bunga Bondar, but also throughout the Sipirok community, shoulder to shoulder regardless of their background, in defense of Indonesian independence.

The security did not improve until the New Order regime. Only then that the implementation of traditions and practices of inter-religious harmony could be reestablished. In 1975 the Muslims and Christians jointly renovated the Bunga Bondar church which was originally under the administration of Huria Christian Batak Protestant Church (HKBP). The renovation carried out in 1975 at the same time formalized the transition of the church's administration to the Huria Christian Protestant Angkola (GKPA). Despite having undergone changes several times, the church in Bunga Bondar was not like a church in the general sense of the word, because it was never been given a name or placard on the yard that indicated that the church was under the administration of a particular institution. This was intended to avoid a perceived exclusivity of a certain church or tribe. In addition, the Church of Bunga Bondar agreed that the church also belonged to Islam. As such, the church was given the proper name of Bunga Bondar Church and not a name that only emphasizeda particular social group. 
The implementation of inter-religious harmony can also be known when the prohibition and sanctions on food stalls operating during the day in the fasting month were issued by the South Tapanuli District Government in 1990. Residents of Bunga Bondar, both Muslims and Christians who were residents of Southern Tapanuli, protested at first because the ban was considered detrimental to some, making it difficult for non-Muslims and Muslims who couldn't fast to eat during the day. Finally, the regulation was cancelled by the Local Government of South Tapanuli Regency.

The spirit of development which was still encouraged by the New Order regime also came to Bunga Bondar Village. The mosque renovation in Bunga Bondar was an initiative of Raja Inal Siregar, governor of North Sumatra Province who originated from Bunga Bondar. The construction of the mosque was jointly carried out by both Muslims and Christians (Sitompul 1986, 58). At the inauguration of the renovation, the mosque of Bunga Bondar village was named after Nur Hudafor the first time. The naming was more administrative in nature and was carried out at the request of the hajis in Bunga Bondar. In the day-to-day use of the mosque, the people of Bunga Bondar Village often called it the Bunga Bondar Mosque, just like the church which is also only named Bunga Bondar Church. In addition, a community hall was built as a special contribution from the Christian residents of Bunga Bondar. The construction of the State Madrasah Aliyah (MAN) was a government initiative through the Ministry of Religious Affairs. However, in the development process, one of the Christians from Mangaraja also donated his land for road construction that could be used to travel from Bunga Bondar Village to MAN.

Religious harmony among the people of Bunga Bondar was not without obstacles. At the end of the 1980s there was an internal Islamic conflict between parguruan (the term use for Muslim congregations in Bunga Bondar) due to the fight for a Muslim priest's position in the mosque provoked by an immigrant Islamic religious teacher named Dasopang from the Padang Lawas area, which gave rise to a security crisis in Bunga Bondar Village.Violence was unavoidable despite no fatalities. Even though they were not directly affected, Christians were also in danger because it was not safe to leave the house. After six months of conflict, deliberation between the king, tribal leaders, community leaders and police representatives resulted in an agreement to expel Dasopang.

The existence of a phenomenon in the era of unlimited government power to punish troublemakers in the New Order regime raised public fear of chaos (Brenne 1999) and finally the situation became safer and the traditions of inter-religious harmony could be carried out properly. Another important factor that makes inter-religious harmony work properly was the economic stability. Economic factors and inter-family problems that often spark religious conflict in other regions, for example the Shia conflict in Sampang, never occurred in Bunga Bondar. Prices of basic needs were stable and food was readily available. The fairly even economic condition of the society facilitated security stability. Migration did not yet cause any cultural or social friction with the local community.

The 1997-1998 monetary crisis devastated the Indonesian economy (Pempel 2015). Even though the villager's economy was also affected, it did not trigger a conflict or riot, including interreligious conflicts such as those that occurred in Poso and Ambon. Most likely this kind of conflict could be avoided because of the absence of economic domination by either Islamic or Christian groups which triggered conflict in other regions in Indonesia.

The dawn of the reform era was marked by the freedom of information as a result of technological progress which also affected the dynamics between Muslims and Christians in Bunga Bondar Village. The people were able to express their opinions, including to criticize the government, and ideas that were different from those that were commonly available, an opportunity that was not available during the New Order regime. This was especially evident after the 9/11 and Bali bombings became known to the people. The spread of these events was massive and continuously succeeded to create strongholds within the society of Bunga Bondar. The sense of solidarity among fellow residents of Bunga Bondar had shifted into solidarity among fellow believers of the same religion. The debate took place at a coffee shop where men gathered, which continued 
to heat up until one day they agreed to unsubscribe to the newspaper so that the debate over media coverage no longer arose.

The migration was a scourge in the defence of the inter-religious harmony tradition in this reform era. Migrants who do not have the same habits as local residents and contradict traditions. threaten the future of inter-religious harmony. However, local residents had little confidence in immigrants, and so far there has never been a conflict between religious groups because both parties are constantly bridging dialogues, especially from the migrants.

\section{Conclusion}

The inter-religious harmony in Bunga Bondar is indicated by the socio-cultural relations of the people through a tradition called marjambar (giving food during religious holidays), collecting money from all residents to buy and slaughter bulls on every religious day. The Christian tolerance is shown by not serving pork in the house. Meanwhile, tolerance spirit from the Muslims is indicated by the permissibility of food stalls to open all day during Ramadan. Community tolerance regarding romance among youths of different religions when it continues into marriage prompts the bride to follow the religion of her future husband. This is based on the patrilinear system of the Batak tribe which positions men as head of the family and who inherit the family name to their children.

Inter-religious harmony survived because of the sense of empathy fostered since childhood when interacting and communicating in the daily lives of its citizens. When Islam and Christianity entered the village, these traditions were adapted to maintain a united, harmonious and civilized society so that such inter-religious harmony inspiredasense of nationality. The tradition of interreligious harmony could last from time to time, from generation to generation, due to the longlasting Mangaraja leadership system that serves well to protect its people and able to solve every community problem. The Mangaraja system creates a civil society that is able to maintain the tradition of inter-religious harmony in the midst of many social, political, economic and cultural changes. The leadership factor and the implementation of tradition as local wisdom produced a model of inter-religious harmony, namely traditional inter-religious harmony among the community.

\section{References}

Brenne, Suzanne. 1999. "On the Public Intimacy of the New Order: Images of Women in the Popular Indonesian Print Media”. Indonesia 67: 13-37. DOI: 10.2307/3351375.

Castles, Lance. 2001. Kehidupan Politik Suatu Karesidenan di Sumatera Timur: Tapanuli 19151940. Jakarta: KPG Kepustakaan Populer Gramedia.

Kuntowijoyo. 2003. Metodologi Sejarah. Yogyakarta: Tiara Wacana.

Kymlicka, Will. 2011. Kewarganegaraan Multikultural. Jakarta: Penerbit Yayasan LP3ES.

Lindsay, Jennifer. 2012. "Heirs to World Culture 1950-1965: An Introduction." In Heirs to World Culture: Being Indonesian, 1950-1965, edited by Lindsay Jennifer and Liem Maya H. T., 1-28. Leiden: Brill. http://www.jstor.org/stable/10.1163/j.ctt1w8h2v2.6.

Marpaung, Adolf Bastian. 2010. Jiwa Kerukunan Masyarakat Sipirok. Pematangsiantar: L-SAPA STT HKBP Pematangsiantar.

Pempel, T. J., and Keiichi Tsunekawa, eds. 2015. Two Crises. Different Outcomes: East Asia and Global Finance. Ithaca; London: Cornell University Press. http://www.jstor.org/stable/ 10.7591/j.ctt1287c8x.

Reid, Anthony. 2018. Indonesia, Revolusi, \& Sejumlah Isu Penting. Jakarta: Prenada.

Sato Shigeru. 1996. "The pangreh praja in Java under Japanese military rule." Bijdragen tot de Taal-, Land- en Volkenkunde Deel 152, 4de Afl., Japan, Indonesia and THE WAR: Myths and realities: 586-608. https://www.jstor.org/stable/27864797. 
Sitompul, A.A. 1986. Perintis Kekristenan di Sumatera Bagian Utara. Jakarta: BPK Gunung Mulia. Steele, Peter. 2012. "Memorializing Colonialism: Images of the Japanese Occupation of Indonesia in Japanese Popular Theatre." Asian Theatre Journal 29, no. 2: 528-49. http://www.jstor.org/ stable/23359528. 